\title{
European Union and the Unites States of America the sources of Perception and Misperception to $\operatorname{Iran}^{1}$
}

\section{Perception and Misperception in International Politics}

In his seminal book, Robert Jervis risen several questions: "What kinds of perceptual errors commonly occur in decision-making? How are beliefs about politics and images of other actors formed and altered? How do decision-makers draw inferences from information, especially information that could be seen contradicting their own views?" (Jervis, 1976, p. 3).

Two sets of significant factors are impacting on decision-making processes as such as domestic determinants and international environment. It seemed, possessing multiple sources of information and its accessibility in the format of big data and open possibility of analyzing it with additional support of the artificial intelligence would finally reduce undesirable aspect of unproved sets of information which usually have founded misperception in formulating some agenda in foreign policy. Despite of the excellent information and the reprocessing technologies, which are supported by the artificial intelligence, still behind it the gathered impressive data can be wrongly perceived by decision makers (Shorey, Howard, 2016, pp. 5032-5055).

Robert Jervis' account in 1976 on sources of perception and misperception in international politics, especially nowadays is prevailing. Despite of accessibility of information technologies there can be observed abundant examples of misperception being simply interpreted as prejudices, stereotypes, emotions and one-sided interpretations. The wrong effect is additionally empowered by misinterpreted facts in perceiving the sources of instability. In international politics we can handle with many examples of misperception of gathered data and false convictions as such as: positive effect of appeasing Hitler's aspiration and the great for durability of the Munich's 1938 conference results, underestimation of the Vietcong's high morale and determination for continuing the fight despite its great losses, overestimation of the role of anti-Hussein opposition in American-British in Iraq. Robert Jervis put emphasis on ill-functioning relations between decision-makers and intelligence community, especially visible in case of wars in Afghanistan and Iraq. Decision-makers expected from the intelligence agencies confirmation of their views on perceived threats, even is it not addressing the reality and overestimated (Jervis, 2011). Counting the costs of misperceived and wrongly processed information or misinterpretation causing bez misleading causing the cascade of an unexpected events, which are usually high and difficult to repair.

${ }^{1}$ Publication financed by NAWA the Polish National Agency for Academic Exchange PPN/ $\mathrm{BEK} / 2018 / 1 / 00323 / \mathrm{DEC} / 1$. 


\section{Iran the history of a villain}

Paul Pillar once noticed "the Islamic Republic of Iran has become, in two senses, an extraordinary preoccupation of the United States. One sense is that Iran is the subject of a strikingly large proportion of discourse about U.S. foreign policy. American pundits and politicians repeatedly mention Iran, usually with specific reference to its nuclear program, as among the biggest threats the United States faces" (Pillar, 2013, p. 211).

"The Great Satan" and the "Axis of Evil" these epithets revealed emotions and prejudices between Teheran and Washington. At least two memorable moments in mutual relations effected in the burden difficult to overcome. The first was related with prime minister Muhammad Mossadegh's decision to nationalize the Anglo-Iranian Oil Company 1951 and excessive reaction of London and Washington. Mossadegh was accused for violating the Western privileges and pro-communistic sentiments. The orchestrated coup d'état and the CIA involvement was heavy blow and bereaved of Iranians naïve illusions on goodwill of American policy to Iran and the Middle East (Kazemzadeh, 2018, pp. 56-72). Paul R. Pillar highlighted "the seizing of the American embassy in Tehran in November 1979 and the holding hostage of 52 Americans for 444 days, until the day Carter left office. The hostage crisis was one of the few international events to have, largely through the medium of television, a profound and sweeping impact on the perceptions and emotions of the American public" and naturally on American policy to Iran (Pillar, 2013, p. 219).

Sanctioning and isolating Iran had become only accessible tool for the consecutive American administrations as an agenda for pursuing foreign policy to Tehran. Contradictory expectations have revealed Washington's indecisiveness to the outcome. In 1984, Iran was enlisted by the US Department of State as sponsor of terrorism. Different targeted sanctions on: trade, finances, assets, oil, gas, technologies, military equipment and limiting activity of some representatives of Iranian authorities should deepen crisis of economy and provoking social tensions and even change of the political system. From the other hand as expected outcome Iranian authorities under pressure should change its foreign policy and accept US grievances. Both approaches have not brought to the expecting outcome.

For decades maintaining regimes of sanctions and maintaining the Iran isolation would not produce for Washington desirable outcome. The only effect was excluding American entrepreneurs and business form the Iranian market. It should be counted in dozens of billions of the US Dollars.

Case study: US sanctions imposed on Iran

\begin{tabular}{||l|l||}
\hline \multicolumn{1}{|c|}{ Type } & \multicolumn{1}{|c||}{ Characteristic } \\
\hline \multicolumn{1}{|c||}{1} & \multicolumn{1}{|c||}{2} \\
\hline $\begin{array}{l}\text { Ban on the U.S. Trade with and In- } \\
\text { vestment in Iran. May 6, 1995) }\end{array}$ & $\begin{array}{l}\text { Bans almost all of the U.S. trade with and investment in Iran, still } \\
\text { in force. }\end{array}$ \\
\hline $\begin{array}{l}\text { U.S. Sanctions Against Foreign } \\
\text { Firms dealing With Iran's Energy } \\
\text { Sector }\end{array}$ & $\begin{array}{l}\text { The Iran Sanctions Act has been amended several times and autho- } \\
\text { rizes the imposition of 5 out of 12 sanctions on firms determined to } \\
\text { have invested more than \$20 million in the Iranian petroleum (oil }\end{array}$ \\
\hline
\end{tabular}




\begin{tabular}{|c|c|}
\hline 1 & 2 \\
\hline & $\begin{array}{l}\text { and gas) sector; bought Iranian oil (unless such country has a sanc- } \\
\text { tions exemption); sold Iran more than } \$ 1 \text { million worth of gasoline } \\
\text { or equipment to import gasoline or refine oil into gasoline; sold } \\
\$ 1 \text { million or more worth of energy equipment to Iran; provided } \\
\text { shipping services to transport oil from Iran; engaged in an energy } \\
\text { joint venture with Iran outside of Iran; or bought Iran's sovereign } \\
\text { debt. Waived in accordance with the JCPOA. }\end{array}$ \\
\hline Sanctions on Iran's Central Bank & $\begin{array}{l}\text { prevents foreign banks that do business with Iran's Central Bank } \\
\text { from opening U.S. accounts, unless a native country of a banks } \\
\text { earns an exemption from the rule by "significantly reducing" their } \\
\text { purchases of Iranian oil. }\end{array}$ \\
\hline $\begin{array}{l}\text { Terrorism List Designation Sanc- } \\
\text { tions }\end{array}$ & $\begin{array}{l}\text { Iran's designation by the Secretary of State as a "state sponsor of } \\
\text { terrorism". }\end{array}$ \\
\hline $\begin{array}{l}\text { Sanctions Against Foreign Firms } \\
\text { that Aid Iran's Weapons of Mass } \\
\text { Destruction Programs }\end{array}$ & The Iran-Syria-North Korea Nonproliferation Act. \\
\hline $\begin{array}{l}\text { Sanctions Against Foreign Firms } \\
\text { that Sell Advanced Arms to Iran }\end{array}$ & $\begin{array}{l}\text { The Iran-Iraq Arms Nonproliferation Act. Provides for U.S. sanc- } \\
\text { tions against foreign firms that sell Iran "destabilizing numbers and } \\
\text { types of conventional weapons" or WMD technology. Remains in } \\
\text { force. }\end{array}$ \\
\hline $\begin{array}{l}\text { Ban on Transactions with Foreign } \\
\text { Entities That Support International } \\
\text { Terrorism }\end{array}$ & $\begin{array}{l}\text { Authorizes a ban on U.S. transactions with entities determined to } \\
\text { be supporting international terrorism. The Order was not limited } \\
\text { to Iran, but several Iranian entities have been designated. Remains } \\
\text { in force. }\end{array}$ \\
\hline $\begin{array}{l}\text { Ban on Transactions with Foreign } \\
\text { Entities that Support Proliferation }\end{array}$ & $\begin{array}{l}\text { Provide for a ban on U.S. transactions with entities determined to } \\
\text { be supporting international proliferation. Numerous Iranian enti- } \\
\text { ties, including the IRGC itself, have been designated. Remains in } \\
\text { force. }\end{array}$ \\
\hline Divestment & $\begin{array}{l}\text { Authorizes and protects from lawsuits various investment manag- } \\
\text { ers who divest from shares of firms that conduct sanctionable busi- } \\
\text { ness with Iran. Remains in force. }\end{array}$ \\
\hline $\begin{array}{l}\text { Sanctions Against Human Rights } \\
\text { Abuses, Internet Monitoring, and } \\
\text { Regional Activities }\end{array}$ & $\begin{array}{l}\text { Various laws and Executive Orders impose sanctions on named } \\
\text { Iranian human rights abusers, on firms that sell equipment Iran } \\
\text { can use to monitor the Internet usage of citizens or employ against } \\
\text { demonstrators and on Iranian persons or entities that suppress hu- } \\
\text { man rights in Syria or contribute to destabilizing Iraq. Remains in } \\
\text { force. }\end{array}$ \\
\hline $\begin{array}{l}\text { Arms Transfer and Missile Sanc- } \\
\text { tions in the Countering America's } \\
\text { Adversaries through Sanctions Act } \\
\text { (CAATSA) }\end{array}$ & $\begin{array}{l}\text { The CAATSA law, signed on August 2, 2017, mandates sanctions } \\
\text { on arms sales to Iran and on entities that "materially contribute" to } \\
\text { Iran's ballistic missile program. }\end{array}$ \\
\hline $\begin{array}{l}\text { May } 8,2018 \text { withdrawal from the } \\
\text { Joint Comprehensive Plan of Ac- } \\
\text { tion (JCPOA) }\end{array}$ & $\begin{array}{l}\text { Two sets of sanctions came into effect August 7, } 2018 \text { restrictions } \\
\text { on: Iran's purchase of U.S. currency; Iran's trade in gold and other } \\
\text { precious metals; and the sale to Iran of auto parts, commercial pas- } \\
\text { senger aircraft, and related parts and services. } \\
\text { Iraq. Remains in force. The second set of sanctions came into effect No- } \\
\text { vember 7, } 2018 \text { restrictions on: Iran's purchase of U.S. currency; Iran's } \\
\text { trade in gold and other precious metals; and the sale to Iran of auto parts, } \\
\text { commercial passenger aircraft, and related parts and services. }\end{array}$ \\
\hline
\end{tabular}

Source: Katzman, 2018. 
The US allies many times risen doubts of rationality in continuation hard policy to Iran, especially when it is harmful for third parties. The US Congress enacted in 1996 a bill that would impose sanctions on any foreign corporation that invested USD 40 million or more in the Iranian oil and gas industry (reduced to USD 20 million after one year) was evident example of influence pro-Israeli lobbies in Congress. The bill was known as the Iran-Libya Sanction Act (ILSA), as Libya was later added by the Senate in response to Iran's procurement of nuclear capabilities and "support of acts of international terrorism. US sanctions were damaging for the economic interests for the European partners" (Fiedler, 2013, pp. 27-38). The U.S. sanctions regime steadily built up over the decades following the 1979 Iranian Revolution. Iran had been designated as terrorism sponsor, the main source of instability at the Middle East and the main promotor of radical antiWestern fundamentalist ideology. Despite of cooperation with Iranian intelligence in tracing Talibs in Afghanistan and Iran benevolent neutrality during the 'Enduring Freedom', president George W. Bush notoriously included Iran in the "axis of evil" club whose unwitting members also counted pre-invasion Iraq and North Korea, and in 2006 depicted the Islamic Republic as the greatest threat to US interests in the Middle East.

In US optics perceived Iran as a villain was paused during Barack Obama administration which was focused in reaching with Teheran the nuclear settlement. In that approach focused on limiting nuclear program, all other issues as Iranian regional activities and its links with Hezbollah and Houthis and missile program were not discussed. Since 2016 with Donald Trump the Iran as villain has reappeared with strength with all estimations focused on Iran as threat and the source of instability.

\section{European Union's perception for sustaining dialogue with Iran}

EU's manner of dealing with the problem by peacefully deterring Iran from developing a nuclear weapon significantly differed from the though approach of the US. The latter's approach was comprised of three core elements: hard sanctions, coercive diplomacy and, finally, a military action as the last resort.

EU had some record in engaging with Iran prior to the nuclear crisis which was erupted in 2002. Between 1992-1997, the EU had endorsed the "Critical Dialogue" to address several issues, including concerns with regard to the human rights. After a yearlong crisis related to the political assassinations in Germany, with the Iranian authorities and ayatollah Ali Khamenei being the main culprit, Muhammad Khatami and his agenda focused on the dialogue with the West, which in turn opened new window for the engagement with Iran. The EU diplomacy was re-commenced under the heading "Comprehensive Dialogue" (1998-2002) to signal a broader approach. While the human rights component became more prominent over time, the Comprehensive Dialogue also addressed areas of cooperation and mutual interest with the long-term ambition to sign a Trade and Cooperation agreement between the EU and Iran (Parsi, 2011). In 1999, the European Union considered entering into negotiations with Iran for a Trade and Cooperation Agreement (TCA), which it needed as a legal framework for its dealings with that country. By offering the TCA as an incentive for such political and economic concessions, the EU wanted to create a stake for Iran which would 
tie the country closer to the EU, both politically and economically Despite many difficulties in 2000, the EU advanced with Iran negotiations on the TCA, which was linked to the Political Dialogue Agreement. Within the scope were four areas: human rights, non-proliferation, terrorism, and the Middle East peace process. The strategy was simple: getting Iran closer to the EU politically and economically, which would allow Europe to extract significant concessions from Tehran. Reciprocity of president Khatami and some improvement in general relations with Iran was promising to more durable connection with Iran (Kaussler, 2014).

Despite of some progress achieved by Mohammad Khatami's government, political dialogue was overshadowed by the nuclear crisis. Between 2003-2006, the EU tried to negotiate with Iran through the EU3 format (Germany, France, Britain) and the High Representative in the person of Javier Solana. In 2004, an agreement (the "Paris agreement") was reached, in line with which Iran would voluntarily suspend its nuclear enrichment activities while further negotiations took place. The Iran-EU3 negotiations lasted through 2005, and Iran submitted various proposals through Hassan Rouhani, nuclear negotiator to the EU3 expressed a readiness to (1) cap enrichment at the 5 percent level; (2) export all low-enriched uranium (LEU) beyond domestic needs or fabricate it into fuel rods; (3) commit to the Additional Protocol and Subsidiary Arrangement Code 3.1 of its safeguards agreement; (4) allow the IAEA to make unannounced and intrusive inspections of undeclared facilities; and (5) engage in no reprocessing of plutonium from the Arak heavy water reactor (Porter, 2012).

However, little progress had been achieved and eventually the process failed for several reasons: (1) the George W. Bush administration in Washington refused to participate in any negotiations initiated by the EU and was not supportive; (2) in 2005 change from moderate to more radical president, the Iranian President Mahmoud Ahmadinejad (2005-2013) was not convinced in negotiations on the nuclear issue and had populist and nationalistic agenda; and (3) EU and US demand for full cessation of enrichment was unacceptable and unfair for Iran, because even in the Non-proliferation Treaty low uranium enrichment for civilian purposes is accepted (Posch, 2015).

Soon after Mahmoud Ahmadinejad had assumed the presidency, Iran restarted its uranium conversion facilities in Isfahan. On September 24, 2005, the IAEA board of governors found Iran to be in noncompliance with its safeguards agreement. On January 10, 2006, Iran resumed enrichment activities at its Natanz plant; on February 3, the IAEA voted to refer the file to the UN Security Council (UNSC) (Fiedler, 2013, pp. 45-60).

The EU's rising irritation with Ahmadinejad's uncompromising policy regarding the nuclear issue together with his nationalistic agenda in the sphere foreign policy had resulted in a tighter cooperation with the US in pursuing more coercive diplomacy to Iran. Convincing Russia and China that Iranian nuclear program should be under more efficient international control was an important achievement, both EU and Bush and Obama administrations. The EU 3 evolved into P 5 plus 1 (US, China, Russia, France, Great Britain and Germany). Wider block and accession of China and Russia, up to know natural Iranian allies was a have blow for Ahmadinejad's foreign policy and posed to be a serious threat for deeper isolation of Iran. Beginning with the UNSCR 1696 in July 2006, a number of UNSC resolutions (UNSCRs 1737 and 1747 in 2007; 
1803 and 1835 in 2008; and 1929 (June 2010) the most comprehensive UN-led sanctions were passed. The EU added its own set of sanctions and restrictions, which had been further regularly updated. In 2012, the EU took restrictions one step further with an EU wide boycott of the import of Iranian oil and gas (Esfandiary, 2013). As a result, the EU's total trade with Iran dropped down to $€ 6$ billion by 2013 from the estimated $€ 27$ billlion in 2011 (Mousavian, 2016, p. 86). In 2010, before comprehensive sanctions were implemented, Iran was the 25th largest EU trading partner, whereas European countries were Iran's major trading partners. EU exports - machinery, transport equipment, manufactured goods and chemicals - accounted for almost a third of Iran's imports, between 10 and 11.3 billion euros. The new round of sanctions puts a great pressure particularly on some countries. In addition to the Greek market, Spain and Italy - the largest European buyers of Iranian crude - buy slightly more than $10 \%$ of their crude from the Islamic Republic, accounting for 6-8\% of Iran's total crude oil exports to the EU (Tabrizi, Santini, 2012). Moreover, the Belgium-based Society for Worldwide Interbank Financial Telecommunication ("SWIFT") the primary provider for transferring information about financial transactions between banks. In 2012, pursuant to US and EU sanctions, SWIFT disconnected Iranian banks from its messaging system (Cronberg, 2018).

The breakthrough came along with by the president's Obama changed approach and the election of the new Iranian president, Hassan Rouhani, in June 2013. All Iranian factions from conservatives to moderates perceived tightening sanctions as a grieve threat for the Islamic Republic and were ready for doing concessions in nuclear program in exchange for lifting sanctions. Concessions seemed not to be so deep. The Obama administration had acknowledged that the goal of making Tehran abandon its nuclear enrichment programme was unrealistic and hard to accept for Iran and finally had accepted EU's position on more realistic agenda towards Iranian low enrichment tolerable for civilian purposes. In addition, with a somewhat more flexible approach set by the new Iranian negotiating team under the foreign minister, Javad Zarif, the negotiations became regular and constructive. In November 2013, the P5+1 and Iran agreed to the Joint Plan of Action, which outlined the future negotiation process and the possible end goal of a comprehensive agreement on Iran's nuclear programme (Rettman, 2014).

Immediately after the signing of the nuclear agreement in the summer of 2015, and even before the sanctions were lifted, delegations of European senior officials and businessmen began regularly visiting Iranian counterparts with the aim of laying the groundwork for investments and economic cooperation. Iranian President Hassan Rouhani made a tour of European capitals, the first visit of its kind in years, in which framework agreements for bilateral trade and economic cooperation were signed. Among the deals concluded since then: Iran purchased some 100 Airbus aircraft from France, after the United States withdrew its objections to this transaction (the first plane arrived in Iran on January 12, 2017); the French automobile companies, Peugeot and Renault, returned their operations to Iran; the French oil company, Total, resumed operations in Iran with additional development in the South Pars gas field in conjunction with a Chinese company - a transaction that is valued at $\$ 6$ billion, energy deals were signed with Italy and the German company Siemens signed an agreement to upgrade Iran's railway infrastructure 
(Germany was formerly Iran's largest trade partner). Also, on the agenda is the resumption of activities in Iran by the British insurance company Lloyds, after a five-year break. This is an important development that was even mentioned by President Rouhani, due to its contribution to lowering Iranian export costs, as Iran had been forced to absorb high costs in recent years because insurance companies, headed by Lloyds, refused to insure Iranian cargos. Alongside these business developments is Iran's reconnection to the Swift global payments system, and thirty Iranian banks have already connected to the system. The return of small European banks to Iran has also contributed to the impressive improvement in Iran's economic situation in 2016 and brought bright prospects for the nearest future (Shine, Catran, 2017).

\section{Why did JCPOA fail?}

On July 14, 2015, Iran and the P5+1 reached an agreement The Joint Comprehensive Plan of Action (JCPOA) which curtailed most of the achievements of Iran's decades-long nuclear endeavor. In December 2015, the International Atomic Energy Agency (IAEA) certified Iran in compliance with the agreement, thus paving the way for implementation of the JCPOA. As a part of the deal, the IAEA promised stringent oversight of Iran's nuclear program to ensure that it would remain peaceful for the duration of the agreement and beyond. It gave mechanisms and instruments for sustaining international surveillance Iranian observance all nuclear deal's provisions. It could be perceived the JCPOA wiped out most of the achievements of Tehran's decades-long nuclear endeavor and focused on restrictions regarding all technical aspects of nuclear program. Iran had been restricted to 6,000 IR-1 first generation centrifuges of limited enrichment capacity. In addition, until 2030, Iran will be limited to a $300 \mathrm{~kg}$ cap on its Low Enriched Uranium (LEU) per year; excess LEU needs to be shipped out of the country. To prevent Iran from cheating a justifiable suspicion given its record, the JCPOA offered a strict safeguards protocol based on electronic monitoring, visit of IAEA inspectors, and unspecified cyber surveillance. (JCPOA, 2015) Depending on the type of activity, the JCPOA restrictions would be lifted in 10-15 years, but the Additional Protocol which Iran is obliged to ratify until 2023 and which it is now voluntarily implementing, would guarantee a stringent IAEA oversight beyond the agreement's expiration date. According to the JCPOA, Iran's total enrichment capacity will remain where it is now until 2028. The level of enrichment is restricted to 3.67 percent until 2030. The path to a plutonium weapon is also blocked by the 15-year ban on constructing a new Heavy-Water Reactor (HWR) and on reprocessing spent fuel. Iran would need 1,400 to 2,800 kg LEU for one single bomb. These limitations make Iran's weaponization almost impossible until 2030 (Final Assessment, 2015).

The EU intelligence agencies confirmed that Iran has not commenced covert nuclear activities since the JCPOA was signed. On September 21, 2017, Federica Mogherini, the European Union's foreign policy chief agreed that Iran was in full compliance of the agreement. On September 5, 2017, Mogherini agreed that the JCPOA "set a milestone for non-proliferation, making everyone more secure - in the region, in Europe, and in the world" (BBC, 2019). 
The IAEA's eights reports since January 16, 2016 (Implementation Day of the JCPOA), up to April 2018 indicated that Iran has fulfilled its JCPOA commitments and did not continue its banned nuclear activities. On May 11, 2017, IAEA director general Yukiya Amano confirmed Iran's compliance. Moreover, on April 18, 2017, the Department of State has certified Iran as being in compliance with the Similarly, Defense Secretary, Jim Mattis, testified before the Senate Armed Services Committee and confirmed that there is no indication that Iran has violated the nuclear agreement (Rezaei, 2018, p. 181).

Unable to find any evidence of Iran's non-compliance with the JCPOA, president Donald Trump had focused on Iran's ballistic missiles program. Missile test in opinion of American officials had violated the spirit of the nuclear agreement prohibited under UNSC Resolution 2231 and should be included as the main issue in new renegotiated nuclear deal with Iran. For president Trump the JCPOA only encouraged Teheran for developing missile program and promoting instability in the Middle East (Dunn, 2018).

Another accusation raised against Iran that the JCPOA Teheran allowed to rise funds from oil and gas export and regain access to unfreeze assets for funding the terror groups and rebel fighters in a number of regional countries comes from the state's annual defense budget. Greater military expenditures include potentially millions of dollars in monthly payments to pro-government forces in Syria, to fighters in Iraq, to Houthis in Yemen and to Hezbollah and Hamas. Estimates for Iran's annual support to the Syrian government range from \$6 billion and in some even up to \$20 billion. Reportedly, the value of Iranian oil transfers, lines of credit, military personnel costs and subsidies for weapons for the Syrian government was around $\$ 3.5$ and $\$ 4$ billion annually. Included in the payment list is the salary of Iranian-backed fighters in Syria who are reportedly paid between $\$ 500$ and $\$ 1,000$ a month to fight for the Assad regime (Rezaei, 2018, pp. 189-191).

Summarizing, despite of nuclear deal accomplishments, its weaknesses have undermined the JCPOA's durability: (1) the agreement did not include the Iranian missile program and has not initiated more comprehensive dialogue with Tehran on its Middle East policy; (2) the nuclear deal has not changed Iran's behavior in regional politics, which threatens Saudi Arabia and Israel close USA allies; (3) the agreement with the international community has not changed Iran's internal political situation and has not initiated political reforms to soften the autocratic regime; (4) the agreement is a disappointment for the Iranian authorities, as the increased scope for inspections and the significantly reduced enrichment of uranium has not led to the upholding of this agreement by the USA and Iranian openness in accessing to its nuclear infrastructure was not noted by Washington as a sign of Teheran goodwill.

\section{Misperception is prevailing: European Union to Donald Trump's confrontational policy to Iran}

From the beginning, president Trump referred to the JCPOA as the worst deal ever negotiated, and several key political appointees were the people known as for example John Bolton, strongly advocated hard line policy to Iran. At the U.N., Trump declared, 
"It is time for the entire world to join us in demanding that Iran's government end its pursuit of death and destruction ... Above all, Iran's government must stop supporting terrorists ... and respect the sovereign rights of its neighbors" (Trump, 2017). One of the security advisors, Michael Flynn issued a statement commenting Iranian missile tests:" the mullahs very well understand the language of force (Alavi, 2017).

President Trump administration formulated four-pillars strategy to the Middle East, which is called the maximum pressure on Iran (Feierstein, 2018):

- Cooperating with US allies to counter the regime's destabilizing activity and support for terrorist proxies in the region;

- Imposing additional sanctions on the regime to block their financing of terror;

- Addressing the regime's proliferation of missiles and weapons that threaten its neighbors, global trade, and freedom of navigation;

- Deny the regime all paths to acquire a nuclear weapon.

The United States Middle East policy under president Trump has been dominated by the hostile attitude to Iran. Beyond the hardline, the administration has not offered a consistent and clear plan for resuming negotiations with Iran, within the new formula as for example JCOPA+. The appointment of Mike Pompeo as secretary of state and John Bolton as national security advisor only empowered continuation of tougher policy or even regime change in Iran. Finally, in May 2008 Trump administration though decision of US withdrawal from JCPOA derailed the nuclear deal. Soon after JCPOA withdrawal, the newly-appointed Secretary of State, Mike Pompeo, set out 12 conditions which Iran must fulfill for any new nuclear agreement to be reached. Conditions refer to ceasing all uranium enrichment; ending the development of nuclear-capable ballistic missiles; termination of Iranian support for Hezbollah, Hamas, Houthi rebels in Yemen, and the Taliban; withdrawal of all Islamic Revolutionary Guard Corps (IRGC) and Iranian proxy forces from Syria; dismantling of IRGC-backed militias in Iraq; and, for good measure, no more chants of "Death to Israel" (Staff, 2018). The diplomatic weakness of the Trump-Pompeo unilateral policy lies in its lack of consideration for the opinions of other parties and the deliberate undermining of all the achievements of the previous administration. This hardline stance regarding Iran causes deepening mistrust and hostility between the two countries. Despite the Iranian authorities traditional Anti-Americanism, the Iranian society is positively viewing the United States, and especially the American way of life. An overly harsh US policy towards Iran could result in pushing Iranians to support their government, by creating the impression that the country is in danger. Trump's plans to engineer social unrest in Iran would be futile if the US reimposes sanctions on Iran without justification.

Throughout the Trump administration, the US's relations with EU have worsened in many areas. The EU has lost a valuable partner in dealing with global problems. Previously, the US-EU joint strategy regarding Iran in 2010-2013 brought Iran back into negotiations. Nowadays, the EU is not only lacking support from the US; in fact, its relations with Iran might additionally increase the tensions between the EU and Washington if Europe continues to engage with Iran. The Trump administration still has at its disposal highly effective secondary sanctions, allowing the United States to threaten sanctions against foreign firms and businesses that deal with Iran. These sanctions essentially is powerful instrument to the American business partners who are forced for making a choice between 
Iran and the United States. Since the United States is the world's largest economy and the center of global finance, it is really no choice at all. European diplomats have also confessed that if the United States reimposes secondary sanctions, it is likely that many European firms would choose to cut economic ties with Iran, regardless of their official government positions, to avoid being cut off from the American financial system.

In the months following the US's withdrawal from the JCPOA, many large European companies have decided to limit its activity in Iran. Total has already announced that it will not develop the South Pars gas field. Maersk and Peugeot have also left Iran. It was also recently reported that many German companies, including truck and car manufacturer Daimler, intend to withdraw from Iran (Czulda, 2018).

The EU's unsuccessful efforts to keep the US in the deal centered on three main areas of interest - firstly, the European Union's principles of international cooperation and as a normative force in the development of an effective security system, non-proliferation and the primacy of diplomacy in resolving international disputes. Secondly, the EU has significant economic and commercial stakes in a viable nuclear deal, and, thirdly, Brussels assesses that the deal has been working to inhibit Iran's acquisition of nuclear weapons capability, and that it therefore strengthens regional and European security. The EU failed to convince the USA of staying within JCPOA. Moreover, the EU was unable to create protective system for sustaining the JCOPA and has not strategy for renewed crisis regarding Iranian nuclear program.

Instruments proposed by the EU has not enough convinced even many European companies. Restated the Blocking Statute allows EU operators to recover damages arising from the extra-territorial sanctions within its scope from the persons causing them and nullifies the effect in the EU of any foreign court rulings based on them. It also forbids EU persons from complying with those sanctions, unless exceptionally authorized to do so by the European Commission in case non-compliance seriously damages their interests or the interests of the Union. To assist EU operators with the implementation of the updated Blocking Statute, the Commission has published a Guidance Note to facilitate the understanding of the relevant legal acts as well as a document explaining its effect. On 31 January 2019, France, Germany and the UK (together, the E3) announced the creation of Instrument for Supporting Trade Exchanges (INSTEX) - a Special Purpose Vehicle for facilitating legitimate trade between European businesses and Iran. The E3 Joint Statement notes that INSTEX will focus "initially on the sectors most essential to the Iranian population - such as pharmaceutical, medical devices and agri-food goods," and that its long-term aim is for it to open up to "economic operators from third countries who wish to trade with Iran" (Joint Statement, 2019).

However, initiated instruments has failed in addressing Iranian needs and reviving the JCOPA. Teheran facing tightened Washington pressure and timid EU countermeasures, on 8 May 2019 Iran has suspended its commitments under the JCPOA to sell surplus of enriched uranium in exchange for natural uranium, and to make excess heavy water available on the open market. Iran urged the E3, Russia and China to fulfil their banking and oil commitments to Iran in the next 60 days, otherwise Iran may not respect the current limits on uranium enrichment and may take measures to modernize the Arak heavy water reactor and suspend implementation of other obligations under the JCPOA (Insight, 2019). 


\section{Final remarks}

Washington mistrust to Iranian intentions are rooted in historical events and Teheran swift from an ally to a hostile country after the revolution in 1979. However, Washington-Teheran complicated relations coincided with timid attempts of both counterparts to repair its relations. Since 1979 following administrations have worked out patterns of policy to Iran, which consists of: hard policy, pressure, sanctions, isolation and intimidation. Iran is also problematic state: human rights abuses, highest rankings of death sentences and double state apparatus with the religious and republican apparatus and divisions, between so called moderates and hard-liners with its foreign policy supporting Shia minorities and Bashar al-Assad.

Donald Trump hostility to Iran is not new in USA policy to Iran since 1979. However, in this wave worrying is the intensity of anti-Iranian policy almost without open door for negotiations. Imposing personal sanctions on the supreme leader Ali Khamenei and the foreign policy minister Javad Zarif only proved lack of consistent strategy toward Iran. Initially it seemed, president Trump was focused on renegotiating the JCPOA, including missile program and Iranian involvement in regional affairs from Yemen to Syria and Lebanon. Nowadays intensifying incidents in the Persian Gulf, especially on the Ormuz Strait could only provoke military clashes or even more intensive military confrontation between USA and Iran. Despite some hawkish rhetoric, Gulf states are nervous about President Donald Trump's policy of imposing "maximum pressure" on Iran. Conflict threatens their infrastructure and could hamper the oil and gas shipments that fill their treasuries (Tensions, 2019).

The EU is perceiving Iran as prospective partner with enormous energy capacity and developing economy (Osiewicz, 2018, pp. 153-160). The EU treated the JCPOA as a symbol of effectiveness of European diplomacy coordinated by the EU institutions. Reopened Iran was a chance for doing business by the European companies and financial institutions. This success story did not prevent from derailing the JCPOA. It seemed the EU is unable to build coalition and introduce instruments for protecting the JCPOA provisions. Decisions-makers in Teheran facing financial crisis have urged EU for greater contribution in averting negative effects of renewed USA sanctions. Iranian impatience of EU responds additionally fueled of USA rising hostility to Teheran only proved the JCPOA is not further reliable formula. Unfortunately, the EU has lost its credibility as an ardent JCPOA defender, For Teheran is losing its negotiation leverage and as a reliable partner.

The EU has still a capacity for resuming negotiations with Teheran. There are at least two risks: 1 . Iranian non-compliance and 2. maintaining by the president Trump maximum pressure and hostile policy to Teheran. Beyond these limitations, both the EU as Iran are urgently needed partners. Iran faced of its infrastructural inferiority, badly needs European investments and technologies.

The EU has lost its credibility, attractiveness and reliability and it would be extremely difficult to repair all damages. Additionally, the EU in the near future would face renewed Iranian nuclear program beyond the JCPOA's provisions. It should be considered, abandoned Teheran is seeking for more tightened cooperation within the Chinese Belt and Road Initiative and Russia as more reliable partners. 


\section{Bibliography}

BBC (2019), Iran nuclear deal breaches not yet significant, EU says, https://www.bbc.com/news/ world-middle-east-48995866, 20.07.2019.

Cherkaoui M. (2018), Trump's Withdrawal from the Iran Nuclear Deal: Security or Economics?, http://studies.aljazeera.net/mritems/Documents/2018/5/10/d6a4c71882da438e9de76152c 7e3a8dc_100.pdf, 20.07.2019.

Cronberg T. (2018), No EU, no Iran deal: the EU's choice between multilateralism and the transatlantic link, "The Nonproliferation Review".

Dunn G. (2018), Iran Sanctions 2.0: the Trump administration completes its abandonment of the Iran nuclear agreement, November.

Esfandiary D. (2013), Assessing the European Union's Sanctions Policy: Iran as a case study, EU nonproliferation papers, no. 34, December 2013, http://www.sipri.org/research/disarmament/eu-consortium/publications/nonproliferation-paper-34, 20.07.2019.

Feierstein G. M. (2018), Trump's Middle East Policy at One Year Policy Lacks Strategic Coherence Despite Rhetoric, "Middle East Institute".

Fiedler R. (2013), Hard power dismisses soft power - the United States' relations with the Iranian Islamic Republic in the shadow of the nuclear program, "Przegląd Politologiczny", no. 3.

Fiedler R. (2017), European Union and the Islamic Republic of Iran, in: Political Dilemmas of the Arab and Muslim World, eds. R. Ożarowski, W. Grabowski, Rambler Press.

Fiedler R. (2018), Domestic sources of Iranian foreign policy. Variables and options, in: Beyond Europe. Politics and Change in Global and Regional Affairs, eds. R. Fiedler, A. Stelmach, Logos Verlag, Berlin.

Final Assessment on Past and Present Outstanding Issues regarding Iran's Nuclear Programme, International Atomic Energy Agency, https://www.iaea.org/sites/default/files/gov-2015-68. pdf, 20.07.2019.

INSIGHT: Iran Sanctions Latest changes \& additions (2019), https://www.skuld.com/topics/legal/ sanctions/iran/insight-iran-sanctions/, 20.07.2019.

Jervis R. (1976), Perception and Misperception in International Politics, Princeton University Press, Princeton-New York.

Jervis R. (2011), Why Intelligence Fails: Lessons from the Iranian Revolution and the Iraq War, Cornell University Press.

Joint Comprehensive Plan of Action, (JCPOA), July 14, 2015, https://www.justsecurity.org/wp-content/uploads/2015/07/271545626-Iran-Deal-Text.pdf, 20.07.2019.

Katzman K. (2018), Iran: Politics, Human Rights, and U.S. Policy, Congressional Research Service, March 26, 2018; https://fas.org/sgp/crs/mideast/RL32048.pdf, 25.06.2019.

Kaussler B. (2008), European Union constructive engagement with Iran (2000-2004): An exercise in conditional human rights diplomacy, "Iranian Studies", 41(3).

Kaussler B. (2014), Iran's Nuclear Diplomacy. Power politics and conflict resolution, London-New York.

Kazemzadeh M. (2018), The sources of the Middle East's crises and American grand strategy, "Comparative Strategy", vol. 37(1),

Osiewicz P. (2018), EU-Iran Relations in the Post-JCPOA Period: Selected Political Aspects, "Przegląd Politologiczny", nr 2.

Pillar R. P. (2013), The Role of Villain: Iran and U.S. Foreign Policy, "Political Science Quarterly", vol. 128 , no. 2 (Summer).

Pohl A. (2018), Główne determinanty polityki bezpieczeństwa Izraela w XXI w., Poznań. 
Posch W., (2015), Iran and the European Union, Iran Primer, USIP, http://iranprimer.usip.org/re source/iran-and-european-union, http://eeas.europa.eu/statements/docs/2013/131219_04_ en.pdf, 20.07.2019.

Rezaei F. (2018), The Three Specific Clusters of Concerns, "Insight Turkey”, vol. 20, no. 2.

Shine S., Catran A. (2017), Europe-Iran Relations One Year after the Sanctions were Lifted, "INSS Insight" no. 888, January 16.

Shorey S., Howard P. N. (2016), Automation, Big Data, and Politics: A Research Review, "International Journal of Communication" 10.

Tensions between Iran and the West have the Gulf states on Edge (2019), https://www.economist. com/middle-east-and-africa/2019/07/25/tensions-between-iran-and-the-west-have-the-gulfstates-on-edge, 20.07.2019.

Trump D. (2017), Remarks by President Trump to the 72nd Session of the United Nations General Assembly, White House, September 19.

\section{Summary}

This article is focused on causes of perception and misperception between the European Union and United States of America in its policies toward Iran. Misperception caused derailing of the Joint Comprehensive Plan of Action (JCPOA) by the USA withdrawal from it. Tracing misperception and perception in policies and strategies to Iran should contribute for better understanding complicated and contradictory relations between the West and Iran.

Key words: JCPOA, perception, misperception, USA, EU

\section{Unia Europejska i USA przyczyny (błędnego) postrzegania Iranu}

\section{Streszczenie}

Celem artykułu jest wskazanie głównych przyczyn (błędnego) postrzegania w polityce USA i Unii Europejskiej wobec Iranu. Błędne postrzeganie intencji Iranu było jedną z głównych przyczyn wykolejenia porozumienia nuklearnego JCPOA było wycofanie się z niego USA. Analizowanie (błędnego) postrzegania ma istotny wpływ na formułowanie polityk i strategii wobec Iranu umożliwia głębsze spojrzenie w skomplikowane relacje pomiędzy Zachodem a Iranem.

Slowa kluczowe: JCPOA, (błędne) postrzeganie, USA, UE 
